\title{
Penyelesaian Integer Linear Programming menggunakan Metode Reduksi Variabel (Studi Kasus: Zee Studio Photography)
}

\author{
Elfira Safitri ${ }^{1}$, Sri Basriati ${ }^{2}$, Clara Ramadhania ${ }^{3}$ \\ ${ }^{1,2,3}$ Program Studi Matematika, Fakultas Sains dan Teknologi, UIN Sultan Syarif Kasim Riau \\ Jl. HR. Soebrantas No. 155 Simpang Baru, Panam, Pekanbaru, 28293 \\ Email: elfira.safitri@uin-suska.ac.id, sribasriati@uin-suska.ac.id, clraramadhania@gmail.com
}

\begin{abstract}
ABSTRAK
ZEE Studio Photography merupakan salah satu studio foto yang memproduksi bingkai foto dengan berbagai ukuran. Pembuatan bingkai foto dengan berbagai ukuran diharapkan memperoleh keuntungan yang besar dengan modal yang sedikit, sehingga sumber daya yang tersedia dapat dioptimalkan dengan baik. Salah satu cara untuk mengoptimalkan masalah tersebut yaitu dengan integer linear programming. Integer linear programming adalah sebuah model penyelesaian matematis yang ha sil penyelesaian kasus linear programming berupa bilangan pecahan diubah menjadi bilangan bulat. Metode yang digunakan untuk menyelesaikan masalah integer linear programming yaitu metode reduksi variabel. Metode reduksi variabel menghasilkan solusi optimal dengan semua variabel keputusan berupa bilangan bulat dengan perhitungan yang lebih sederhana tanpa harus menambah kendala gomory ataupun membuat percabangan. Berdasarkan hasil penelitian bahwa ZEE Studio Photography memproduksi 2 bingkai foto ukuran 24R dan 2 bingkai foto ukuran 36 dengan keuntungan sebesar Rp.500.000.
\end{abstract}

Kata Kunci: Integer Linear Programming, kendala gomory, Percabangan, Reduksi Variabel, ZEE Studio Photography

\begin{abstract}
Zee Studio Photography is a photo studio that produces photo frames of various sizes. Making photo frames of various sizes is expected to obtain large profits with little capital, so that the available resources can be optimized properly. One way to optimize the problem is with integer linear programming. Integer linear programming is a mathematical settlement model in which the results of solving linear programming cases in the form of fractions are converted into integers. The method used to solve the problem of integer linear programming is the branch plane and bound cutting method and variable reduction. Based on the results of the study note that the completion of integer linear programming using the variable reduction method produces an optimal solution with all decision variables in the form of integers with simple calculations without having to add gomory constraints or make branches. Based on the results of the study, ZEE Studio Photography obtained a profit of Rp.500,000 by producing $224 R$ photo frames and producing $236 R$ photo frames.
\end{abstract}

Keywords: Branching, Integer Linear Programming, Gomory constraints, Variable Reduction, ZEE Studio Photography

\section{Pendahuluan}

Integer linear programming adalah sebuah model penyelesaian matematis yang hasil penyelesaian kasus linear programming berupa bilangan pecahan diubah menjadi bilangan bulat. Metode yang umum digunakan untuk menyelesaikan masalah integer linear programming yaitu metode cutting plane dan metode branch and bound [8].

Solusi optimum bilangan bulat pada metode cutting plane dapat di selesaikan dengan menggunakan metode simpleks dan metode dual simpleks serta menambahkan pembatas baru (gomory).Sedangkan solusi optimum bilangan bulat pada metode branch and bound di selesaikan dengan menggunakan metode simpleks atau metode grafik jika menggunakan dua variabel. Penyelesaian dengan metode branch and bound, apabila solusi bukan bilangan bulat maka dilakukan pencabangan masalah menjadi dua submasalah. Sehingga diperoleh solusi yang dibutuhkan [7].

Metode reduksi variabel adalah sebuah metode yang dapat digunakan untuk menyelesaikan masalah program linear bilangan bulat murni. Metode reduksi variabel didasarkan pada konsep matematika sederhana. Metode ini lebih sederhana dan perhitungannya sangat mudah daripada metode Branch and Bound dan metode Cutting Plane [6]. 
Berdasarkan penelitian Pandian, dkk [6] yang berjudul " A New Approach for Solving a Class of Pure Integer Linear Programming Problems" memperkenalkan metode baru untuk masalah program linear bilangan bulat murni yaitu metode reduksi variabel yang memiliki paling banyak dua variabel dan dua kendala. Dalam penelitian ini menyimpulkan bahwa metode reduksi variabel lebih baik daripada metode Branch and Bound dan Cutting Plane.

Berdasarkan penelitian Novtaria, Pesti dan Bahri, Susila [4] yang berjudul "Penyelesaian Masalah Pemrograman Linier Bilangan Bulat Murni dengan Metode Reduksi Variabel" menyimpulkan bahwa pemograman linier bilangan bulat murni dua variabel pada kasus maksimisasi dengan metode reduksi variabel menghasilkan solusi yang optimal dengan variabel keputusan bilangan bulat murni yang perhitungannya lebih mudah dan sederhana.

Semakin berkembangnya ilmu pengetahuan maka ditemukan metode baru untuk menyelesaikan permasalahan integer linear programming yaitu metode reduksi variabel oleh Pandian, dkk [6]. Berdasarkan penelitian Pandian, dkk dan Novtaria, Pesti \& Bahri, Susila [4] yang membahas dua variabel keputusan dan dua kendala, maka penulis tertarik untuk membahas metode reduksi variabel dengan lima variabel keputusan dan lima kendala dengan studi kasus yang berbeda. Metode ini melibatkan pemindahan suatu variabel keputusan ke sisi lain dari sebuah fungsi kendala. Adapun tujuan dari penelitian ini adalah untuk mengetahui penyelesaian integer linear programming menggunakan reduksi variabel.

\section{Metode dan Bahan Penelitian}

Data yang digunakan pada penelitian ini adalah data sekunder yang diambil dari ZEE studio photography. Adapun metode yang digunakan dalam pembahasan ini adalah metode reduksi variabel.

\section{Integer Linear Programming}

Secara umum, model masalah integer linear programming dengan fungsi tujuan memaksimumkan dapat dibentuk dalam persamaan berikut:

$$
\begin{aligned}
\text { maks } z & =\sum_{j=1}^{n} c_{j} x_{j} \\
\text { kendala } & \\
& \sum_{j=1}^{n} a_{i j} x_{j} \leq b_{i} \\
& x_{j} \geq 0 \text { untuk } i=1,2, \ldots, m \text { dan } j=1,2, \ldots, n \\
& x_{j} \in \text { integer }
\end{aligned}
$$

\section{Metode Reduksi Variabel}

Metode reduksi variabel merupakan sebuah metode baru yang dapat digunakan untuk menyelesaikan masalah integer linear programming. Metode ini melibatkan pemindahan suatu variabel keputusan ke sisi lain dari sebuah fungsi kendala [6]. berikut:

Adapun langkah-langkah penyelesaian metode reduksi variabel untuk $n$ variabel adalah sebagai

1. Asumsikan masalah integer linear programming pada Persamaan $(1)$ sebagai $(P)$. Kemudian menentukan nilai minimum dari nilai-nilai bilangan bulat terbesar yang mungkin dari $x_{j}$ yang dinotasikan dengan $x_{j}^{*}$ menggunakan Persamaan berikut:

$$
x_{j}^{*}=\min \left\{\left[\frac{b_{i}}{a_{i j}}\right]\right\} \text { dengan } i=1,2, \ldots, 5 ; j=1,2, \ldots, 5
$$

Jika hasil nilai minimum dari $x_{j}^{*}$ sama maka pilih salah satu nilai yang positif. Jika hasil nilai minimum dari $x_{j}^{*}$ berbeda maka pilih nilai positif terkecil. Jika terdapat hasil yang bernilai 0 maka tidak perlu dipilih. $\bar{x}_{r} \in\left\{0,1,2, \ldots, U_{r}\right\}, U_{r}$ berhubungan dengan $x_{j}^{*}$, dimana $U_{r}$ adalah nilai bilangan bulat terbesar dari $\bar{x}_{r}$ yaitu $x_{j}^{*}$. 
2. Asumsikan masalah integer linear programming sebagai $\left(P\left(\bar{x}_{r}\right)\right)$ untuk setiap $\bar{x}_{r} \in\left\{0,1,2, \ldots, U_{r}\right\}$ yang melibatkan $n-1$ pada variabel $x_{j}$ dimana $j \neq r$. Sehingga permasalahan integer linear programming dengan fungsi tujuan memaksimumkan dapat dibentuk menjadi:

$$
\begin{array}{ll}
\text { Maks } z= & \sum_{\substack{j=1 \\
j \neq r}}^{n} c_{j} x_{j} \\
\text { kendala } & \\
& \sum_{\substack{j=1 \\
j \neq r}}^{n} a_{i j} x_{j} \leq b_{i}-a_{r} \bar{x}_{r} \\
& x_{j} \geq 0, \text { untuk } i=1,2, \ldots, 5 \text { dan } j=1,2,, \ldots, 5 \\
& j \neq r \in \text { integer }
\end{array}
$$

3. Menentukan nilai minimum dari nilai-nilai bilangan bulat terbesar yang mungkin dari $x_{j}$ yang dinotasikan dengan $x_{j}^{*}, j \neq r$ dalam permasalahan $\left(P\left(\bar{x}_{r}\right)\right)$ untuk setiap $\bar{x}_{r} \in\left\{0,1,2, \ldots, U_{r}\right\}$. Kemudian subtitusi nilai $\bar{x}_{r} \in\left\{0,1,2, \ldots, U_{r}\right\}$ ke Persamaan berikut:

$$
x_{j}^{*}=\min \left\{\left[\frac{b_{i}-a_{r} \bar{x}_{r}}{a_{i j}}\right]\right\} \text { dengan } i=1,2, \ldots, 5 ; j=1,2, \ldots, 5
$$

Jika hasil nilai minimum dari $x_{j}^{*}$ sama maka pilih salah satu nilai yang positif. Jika hasil nilai minimum dari $x_{j}^{*}$ berbedamaka pilih nilai positif terkecil.Jika terdapat hasil yang bernilai 0 maka tidak perlu dipilih. $\bar{x}_{t} \in\left\{0,1,2, \ldots, U_{t}\right\}, U_{t}$ berhubungan dengan $x_{j}^{*}$, dimana $U_{t}$ adalah nilai bilangan bulat terbesar dari $\bar{x}_{t}$ yaitu $x_{j}^{*}$.

4. Asumsikan masalah integer linear programming sebagai $\left(P\left(\bar{x}_{r}, \bar{x}_{t}\right)\right)$ untuk setiap $\bar{x}_{r} \in$ $\left\{0,1,2, \ldots, U_{r}\right\}$ dan $\bar{x}_{t} \in\left\{0,1,2, \ldots, U_{t}\right\}$ yang melibatkan $5-2$ pada variabel $x_{j}$ dimana $j \neq r, t$. Sehingga permasalahan integer linear programming dengan fungsi tujuan memaksimumkan dapat dibentuk menjadi:

$$
\begin{array}{cl}
\text { Maks } z= & \sum_{\substack{j=1 \\
j \neq r}}^{n} c_{j} x_{j} \\
\text { kendala } & \sum_{\substack{j=1 \\
j \neq r}}^{n} a_{i j} x_{j} \leq b_{i}-a_{r} \bar{x}_{r}-a_{t} \bar{x}_{t} \\
& x_{j} \geq 0, \text { untuk } i=1,2, \ldots, 5 \text { dan } j=1,2, \ldots, 5 \\
& j \neq r, t \in \text { integer }
\end{array}
$$

5. Melakukan Langkah 3 dan Langkah 4 , sehingga terbentuk sebuah set dari permasalah integer linear programming yaitu $\left(P\left(\bar{x}_{r}, \bar{x}_{t}, \ldots, \bar{x}_{k}\right)\right)$ untuk setiap $\bar{x}_{k} \in\left\{0,1,2, \ldots, U_{k}\right\}$ yang melibatkan beberapa variabel keputusan yang telah diperoleh.

6. Menyelesaikan sebuah set dari permasalahan integer linear programming yang ada pada Langkah 5 dengan cara:

$$
\text { Maks } z=\left\{\sum_{\substack{j=1 \\ j \neq r, t, \ldots, k}}^{n} c_{j} x_{j} ;\left(\bar{x}_{r}, \bar{x}_{t}, \ldots, \bar{x}_{k}\right) \in W\right\}
$$

dimana

$$
W=\left\{\left(\bar{x}_{r}, \bar{x}_{t}, \ldots, \bar{x}_{k}\right) ; \bar{x}_{k} \in\left\{0,1,2, \ldots, U_{k}\right\} \text { dan } x_{j}^{*}=\min \left\{\left[\frac{b_{i}-a_{k} \bar{x}_{k}}{a_{i j}}\right]\right\}\right\}
$$

Subtitusi $\bar{x}_{k} \in\left\{0,1,2, \ldots, U_{k}\right\}$ ke dalam Persamaan berikut:

$$
x_{j}^{*}=\min \left\{\left[\frac{b_{i}-a_{k} \bar{x}_{k}}{a_{i j}}\right]\right\} \text { dengan } i=1,2, \ldots, 5 ; j=1,2, \ldots, 5
$$

7. Menentukan calon solusi optimumz. Solusi optimaum untuk kasus maksimum diperoleh dengan cara memilih $z$ yang bernilai positif terbesar. 


\section{Hasil dan Pembahasan}

\section{Gambaran Data}

Berdasarkan data yang diperoleh dari studio foto Zee Studio Photography, diketahui bahwa studio foto memproduksi lima jenis ukuan bingkai foto dengan masing-masing keuntungan yang diperoleh.

Tabel 1. Keuntungan Produksi Bingkai Foto Berdasarkan Ukuran

\begin{tabular}{|c|c|c|}
\hline No & Ukuran & Keuntungan \\
\hline 1 & $10 \mathrm{R}$ & Rp. 30.000 \\
\hline 2 & $16 \mathrm{R}$ & Rp. 50.000 \\
\hline 3 & $20 \mathrm{R}$ & Rp. 75.000 \\
\hline 4 & $24 \mathrm{R}$ & Rp. 100.000 \\
\hline 5 & $36 \mathrm{R}$ & Rp. 150.000 \\
\hline
\end{tabular}

(Sumber: Skripsi Widya Wifaulita, 2016)

Berikut adalah rincian bahan baku untuk memproduksi masing-masing bikai foto dan kapasitas yang tersedia di studio foto Zee Studio Photography:

Tabel 2. Bahan Baku Produksi Bingkai Foto

\begin{tabular}{|c|c|c|c|c|c|c|c|}
\hline \multirow{2}{*}{ No } & \multirow{2}{*}{ Bahan Baku } & \multicolumn{5}{|c|}{ Ukuran } & \multirow{2}{*}{ Kapasitas } \\
\cline { 3 - 7 } & & $10 \mathrm{R}$ & $16 \mathrm{R}$ & $20 \mathrm{R}$ & $24 \mathrm{R}$ & $36 \mathrm{R}$ & \\
\hline 1 & Kayu & $150 \mathrm{~cm}$ & $200 \mathrm{~cm}$ & $200 \mathrm{~cm}$ & $250 \mathrm{~cm}$ & $350 \mathrm{~cm}$ & $1200 \mathrm{~cm}$ \\
\hline 2 & Mdf & $600 \mathrm{~cm}^{2}$ & $1200 \mathrm{~cm}^{2}$ & $2400 \mathrm{~cm}^{2}$ & $3000 \mathrm{~cm}^{2}$ & $5400 \mathrm{~cm}^{2}$ & $50400 \mathrm{~cm}^{2}$ \\
\hline 3 & Kaca & $600 \mathrm{~cm}^{2}$ & $1200 \mathrm{~cm}^{2}$ & $2400 \mathrm{~cm}^{2}$ & $3000 \mathrm{~cm}^{2}$ & $5400 \mathrm{~cm}^{2}$ & $21600 \mathrm{~cm}^{2}$ \\
\hline 4 & Paku Flexi & 8 buah & 12 buah & 16 buah & 20 buah & 24 buah & 125 buah \\
\hline 5 & Paku Siku & 6 unit & 8 buah & 10 buah & 12 unit & 15 buah & 125 buah \\
\hline
\end{tabular}

(Sumber: Skripsi Widya Wifaulita, 2016) berikut:

Berdasarkan data Tabel 1 dan Tabel 2, maka dapat dibentuk Model integer linear programming

Maks $z=30000 x_{1}+50000 x_{2}+75000 x_{3}+100000 x_{4}+150000 x_{5}$

kendala:

$$
\begin{aligned}
& 150 x_{1}+200 x_{2}+200 x_{3}+250 x_{4}+350 x_{5} \leq 1200 \\
& 600 x_{1}+1200 x_{2}+2400 x_{3}+3000 x_{4}+5400 x_{5} \leq 50400 \\
& 600 x_{1}+1200 x_{2}+2400 x_{3}+3000 x_{4}+5400 x_{5} \leq 21600 \\
& 8 x_{1}+12 x_{2}+16 x_{3}+20 x_{4}+24 x_{5} \leq 125 \\
& 6 x_{1}+8 x_{2}+10 x_{3}+12 x_{4}+15 x_{5} \leq 125 \\
& x_{1}, x_{2}, x_{3}, x_{4}, x_{5} \geq 0 \\
& x_{1}, x_{2}, x_{3}, x_{4}, x_{5} \in \text { integer }
\end{aligned}
$$

dimana:

$x_{1} \quad$ Jumlah bingkai foto ukuran $10 \mathrm{R}$ yang diproduksi

$x_{2}$ : Jumlah bingkai foto ukuran 16R yang diproduksi

$x_{3}$ : Jumlah bingkai foto ukuran 20R yang diproduksi

$x_{4}$ : Jumlah bingkai foto ukuran 24R yang diproduksi

$x_{5}$ : Jumlah bingkai foto ukuran 36R yang diproduksi

\section{Langkah-Langkah Penyelesaian Metode Reduksi Variabel}

Langkah 1:Asumsikan masalah integer linear programmingsebagai $(P)$. Kemudian menentukan nilai minimum dari nilai-nilai bilangan bulat terbesar $x_{j}$ yang dinotasikan dengan $x_{j}^{*}$ menggunakan Persamaan (1):

a. $\quad$ Nilai bilangan bulat terbesar yang mungkin dari $x_{1}$ adalah:

$$
\begin{aligned}
x_{1}^{*} & =\min \left\{\left[\frac{b_{1}}{a_{11}}\right],\left[\frac{b_{2}}{a_{21}}\right],\left[\frac{b_{3}}{a_{31}}\right],\left[\frac{b_{4}}{a_{41}}\right],\left[\frac{b_{5}}{a_{51}}\right]\right\} \\
& =\min \left\{\left[\frac{1200}{150}\right],\left[\frac{50400}{600}\right],\left[\frac{21600}{600}\right],\left[\frac{125}{8}\right],\left[\frac{125}{6}\right]\right\} \\
& =\min \{8,84,36,16,21\} \\
x_{1}^{*} & =8 .
\end{aligned}
$$

b. $\quad$ Nilai bilangan bulat terbesar yang mungkin dari $x_{2}$ adalah:

$$
x_{2}^{*}=\min \left\{\left[\frac{b_{1}}{a_{12}}\right],\left[\frac{b_{2}}{a_{22}}\right],\left[\frac{b_{3}}{a_{32}}\right],\left[\frac{b_{4}}{a_{42}}\right],\left[\frac{b_{5}}{a_{52}}\right]\right\}
$$




$$
\begin{aligned}
& =\min \left\{\left[\frac{1200}{200}\right],\left[\frac{50400}{1200}\right],\left[\frac{21600}{1200}\right],\left[\frac{125}{12}\right],\left[\frac{125}{8}\right]\right\} \\
& =\min \{6,42,18,10,16\} \\
x_{2}^{*} & =6 .
\end{aligned}
$$

Perhitungan yang sama dilakukan, sehingga diperoleh $x_{3}^{*}=6, x_{4}^{*}=4$ dan $x_{5}^{*}=3$.

Berdasarkan nilai minimum dari nilai-nilai bilangan bulat terbesar yang dipilih yaitu $x_{5}^{*}=3$. $\bar{x}_{r}=x_{5} \in\{0,1,2,3\}, 3$ berhubungan dengan $x_{5}^{*}$, dimana 3 adalah nilai bilangan bulat terbesar dari $\bar{x}_{r}$ yaitu $x_{5}^{*}$.

Langkah 2: Asumsikan masalah integer linear programming sebagai $\left(P\left(\bar{x}_{r}\right)\right)$ untuk setiap $\bar{x}_{r}=$ $x_{5} \in\{0,1,2,3\}$ yang melibatkan $5-1$ pada variabel $x_{j}$ dimana $j \neq r$. Berdasarkan Persamaan (3) permasalahan integer linear programming berubah menjadi:

Maks $z=30000 x_{1}+50000 x_{2}+75000 x_{3}+100000 x_{4}+150000 x_{5}$

kendala:

$$
\begin{aligned}
& 150 x_{1}+200 x_{2}+200 x_{3}+250 x_{4} \leq 1200-350 x_{5} \\
& 600 x_{1}+1200 x_{2}+2400 x_{3}+3000 x_{4} \leq 50400-5400 x_{5} \\
& 600 x_{1}+1200 x_{2}+2400 x_{3}+3000 x_{4} \leq 21600-5400 x_{5} \\
& 8 x_{1}+12 x_{2}+16 x_{3}+20 x_{4} \leq 125-24 x_{5} \\
& 6 x_{1}+8 x_{2}+10 x_{3}+12 x_{4} \leq 125-15 x_{5} \\
& x_{1}, x_{2}, x_{3}, x_{4}, x_{5} \geq 0 \\
& x_{1}, x_{2}, x_{3}, x_{4} . x_{5} \in \text { integer }
\end{aligned}
$$

Langkah 3: Menentukan nilai minimum dari nilai-nilai bilangan bulat terbesar yang mungkin dari $x_{j}$ yang dinotasikan dengan $x_{j}^{*}, j \neq r$ dalam permasalahan $\left(P\left(\bar{x}_{r}\right)\right)$ untuk setiap $\bar{x}_{r}=x_{5} \in\{0,1,2,3\}$. Kemudian subtitusi $x_{5} \in\{0,1,2,3\}$ ke Persamaan (4):

a. Nilai bilangan bulat terbesar yang mungkin dari $x_{1}$ adalah:

$$
x_{1}^{*}=\min \left\{\begin{array}{c}
{\left[\frac{1200-350 x_{5}}{150}\right],\left[\frac{50400-5400 x_{5}}{600}\right],\left[\frac{21600-5400 x_{5}}{600}\right],} \\
{\left[\frac{125-24 x_{5}}{8}\right],\left[\frac{125-15 x_{5}}{6}\right]}
\end{array}\right\}
$$

Sehingga diperoleh:

Jika $x_{5}=0$, maka

$$
\begin{aligned}
& x_{1}^{*}=\min \left\{\begin{aligned}
& {\left[\frac{1200-350(0)}{150}\right],\left[\frac{50400-5400(0)}{600}\right],\left[\frac{21600-5400(0)}{600}\right], } \\
& {\left[\frac{125-24(0)}{8}\right],\left[\frac{125-15(0)}{6}\right] }
\end{aligned}\right\} \\
&=\min \{8,84,36,16,21\}=8 .
\end{aligned}
$$

Perhitungan yang sama dilakukan, maka diperoleh:

Jika $x_{5}=1$ maka $x_{1}^{*}=\min \{6,75,27,13,18\}=6$,

Jika $x_{5}=2$ maka $x_{1}^{*}=\min \{3,66,18,10,16\}=3$,

Jika $x_{5}=3$ maka $x_{1}^{*}=\min \{1,57,9,7,13\}=1$.

b. Nilai bilangan bulat terbesar yang mungkin dari $x_{2}$ adalah:

$$
x_{2}^{*}=\min \left\{\begin{array}{c}
{\left[\frac{1200-350 x_{5}}{200}\right],\left[\frac{50400-5400 x_{5}}{1200}\right],\left[\frac{21600-5400 x_{5}}{1200}\right],} \\
{\left[\frac{125-24 x_{5}}{12}\right],\left[\frac{125-15 x_{5}}{8}\right]}
\end{array}\right\}
$$

Sehingga diperoleh:

Jika $x_{5}=0$ maka 


$$
\begin{aligned}
x_{2}^{*} & =\min \left\{\begin{array}{r}
{\left[\frac{1200-350(0)}{200}\right],\left[\frac{50400-5400(0)}{1200}\right],\left[\frac{21600-5400(0)}{1200}\right],} \\
{\left[\frac{125-24(0)}{12}\right],\left[\frac{125-15(0)}{8}\right]}
\end{array}\right\} \\
& =\min \{6,42,18,10,16\}=6 .
\end{aligned}
$$

Perhitungan yang sama dilakukan, maka diperoleh:

Jika $x_{5}=1$ maka $x_{2}^{*}=\min \{4,37,13,8,13\}=4$,

Jika $x_{5}=2$ maka $x_{2}^{*}=\min \{2,33,9,6,12\}=2$,

Jika $x_{5}=3$ maka $x_{2}^{*}=\min \{1,28,4,4,10\}=1$.

c. Nilai bilangan bulat terbesar yang mungkin dari $x_{3}$ adalah:

$$
x_{3}^{*}=\min \left\{\begin{array}{c}
{\left[\frac{1200-350 x_{5}}{200}\right],\left[\frac{50400-5400 x_{5}}{2400}\right],\left[\frac{21600-5400 x_{5}}{2400}\right],} \\
{\left[\frac{125-24 x_{5}}{16}\right],\left[\frac{125-15 x_{5}}{10}\right]}
\end{array}\right\}
$$

Sehingga diperoleh:

Jika $x_{5}=0$ maka

$$
\begin{aligned}
x_{3}^{*} & =\min \left\{\begin{array}{r}
{\left[\frac{1200-350(0)}{200}\right],\left[\frac{50400-5400(0)}{2400}\right],\left[\frac{21600-5400(0)}{2400}\right],} \\
=\min \{6,21,9,8,13\}=6 .
\end{array}\right\}
\end{aligned}
$$

Perhitungan yang sama dilakukan, maka diperoleh:

Jika $x_{5}=1$ maka $x_{3}^{*}=\min \{4,19,7,6,11\}=4$,

Jika $x_{5}=2$ maka $x_{3}^{*}=\min \{2,16,4,5,9\}=2$,

Jika $x_{5}=3$ maka $x_{3}^{*}=\min \{1,14,2,3,8\}=1$.

d. Nilai bilangan bulat terbesar yang mungkin dari $x_{4}$ adalah:

$$
x_{4}^{*}=\min \left\{\begin{array}{c}
{\left[\frac{1200-350 x_{5}}{250}\right],\left[\frac{50400-5400 x_{5}}{3000}\right],\left[\frac{21600-5400 x_{5}}{3000}\right],} \\
{\left[\frac{125-24 x_{5}}{20}\right],\left[\frac{125-15 x_{5}}{12}\right]}
\end{array}\right\}
$$

Sehingga diperoleh:

$$
\begin{aligned}
& \text { Jika } x_{5}=0 \text { maka } \\
& \left.\begin{array}{rl}
x_{4}^{*}=\min \left\{\left[\frac{1200-350(0)}{250}\right],\left[\frac{50400-5400(0)}{3000}\right],\left[\frac{21600-5400(0)}{3000}\right],\right. \\
\quad\left[\frac{125-24(0)}{20}\right],\left[\frac{125-15(0)}{12}\right]
\end{array}\right\} \\
& =\min \{5,17,7,6,10\}=5
\end{aligned}
$$

Perhitungan yang sama dilakukan, maka diperoleh:

Jika $x_{5}=1$ maka $x_{4}^{*}=\min \{3,15,5,5,9\}=3$,

Jika $x_{5}=2$ maka $x_{4}^{*}=\min \{2,13,4,4,8\}=2$,

Jika $x_{5}=3$ maka $x_{4}^{*}=\min \{1,11,2,3,7\}=1$.

Nilai minimum dari nilai-nilai bilangan bulat terbesar yang diperoleh $x_{1}^{*}=1, x_{2}^{*}=1, x_{3}^{*}=1, x_{4}^{*}=$ 1, maka pilih salah satu variabel keputusan yaitu $x_{1}^{*}=1 . \bar{x}_{t}=x_{1} \in\{0,1\}, 1$ berhubungan dengan $x_{1}^{*}$, dimana 1 adalah nilai bilangan bulat terbesar dari $\bar{x}_{t}$ yaitu $x_{1}^{*}$.

Langkah 4: Asumsikan masalah integer linear programming sebagai $\left(P\left(\bar{x}_{r}, \bar{x}_{t}\right)\right)$ untuk setiap $\bar{x}_{r}=x_{5} \in\{0,1,2,3\}$ dan $\bar{x}_{t}=x_{1} \in\{0,1\}$ yang melibatkan $5-2$ pada variabel $x_{j}$ dimana $j \neq r, t$. Berdasarkan Persamaan (5) permasalahan integer linear programming berubah menjadi:

Maks $z=30000 x_{1}+50000 x_{2}+75000 x_{3}+100000 x_{4}+150000 x_{5}$

kendala:

$$
\begin{aligned}
& 200 x_{2}+200 x_{3}+250 x_{4} \leq 1200-350 x_{5}-150 x_{1} \\
& 1200 x_{2}+2400 x_{3}+3000 x_{4} \leq 50400-5400 x_{5}-600 x_{1} \\
& 1200 x_{2}+2400 x_{3}+3000 x_{4} \leq 21600-5400 x_{5}-600 x_{1}
\end{aligned}
$$




$$
\begin{aligned}
& 12 x_{2}+16 x_{3}+20 x_{4} \leq 125-24 x_{5}-8 x_{1} \\
& 8 x_{2}+10 x_{3}+12 x_{4} \leq 125-15 x_{5}-6 x_{1} \\
& x_{1}, x_{2}, x_{3}, x_{4}, x_{5} \geq 0 \\
& x_{1}, x_{2}, x_{3}, x_{4}, x_{5} \in \text { integer }
\end{aligned}
$$

Langkah 5: Menentukan nilai minimum dari nilai-nilai bilangan bulat terbesar yang mungkin dari $x_{j}$ yang dinotasikan dengan $x_{j}^{*}, j \neq r, t$ dalam permasalahan $\left(P\left(\bar{x}_{r}, \bar{x}_{t}\right)\right)$ untuk setiap $\bar{x}_{r}=x_{5} \in\{0,1,2,3\}$ dan $\bar{x}_{t}=x_{1} \in\{0,1\}$. Kemudian subtitusi $x_{5} \in\{0,1,2,3\}$ dan $x_{1} \in\{0,1\}$ ke dalam Persamaan (5):

a. Nilai bilangan bulat terbesar yang mungkin dari $x_{2}$ adalah:

$$
x_{2}^{*}=\min \left\{\begin{array}{c}
{\left[\frac{1200-350 x_{5}-150 x_{1}}{200}\right],\left[\frac{50400-5400 x_{5}-600 x_{1}}{1200}\right],} \\
{\left[\frac{21600-5400 x_{5}-600 x_{1}}{1200}\right],\left[\frac{125-24 x_{5}-8 x_{1}}{12}\right],} \\
{\left[\frac{125-15 x_{5}-6 x_{1}}{8}\right]}
\end{array}\right\}
$$

Sehingga diperoleh:

Jika $x_{5}=x_{1}=0$ maka

$$
x_{2}^{*}=\min \left\{\begin{array}{c}
{\left[\frac{1200-350(0)-150(0)}{200}\right],\left[\frac{50400-5400(0)-600(0)}{1200}\right],} \\
{\left[\frac{21600-5400(0)-600(0)}{1200}\right],\left[\frac{125-24(0)-8(0)}{12}\right],} \\
{\left[\frac{125-15(0)-6(0)}{8}\right]}
\end{array}\right\}
$$

$$
=\min \{6,42,18,10,16\}=6 \text {. }
$$

Perhitungan yang sama dilakukan, maka diperoleh:

Jika $x_{5}=1, x_{1}=1$ maka $x_{2}^{*}=\min \{3,37,13,8,13\}=3$,

Jika $x_{5}=2, x_{1}=0$ maka $x_{2}^{*}=\min \{2,33,9,6,12\}=2$,

Jika $x_{5}=3, x_{1}=0$ maka $x_{2}^{*}=\min \{1,28,4,4,10\}=1$,

Jika $x_{5}=2, x_{1}=1$ maka $x_{2}^{*}=\min \{2,32,8,6,11\}=2$,

Jika $x_{5}=3, x_{1}=1$ maka $x_{2}^{*}=\min \{0,28,4,4,9\}=0$.

Nilai bilangan bulat terbesar yang mungkin dari $\mathrm{x}_{5}$ adalah:

$$
x_{3}^{*}=\min \left\{\begin{array}{c}
{\left[\frac{1200-350 x_{5}-150 x_{1}}{200}\right],\left[\frac{50400-5400 x_{5}-600 x_{1}}{2400}\right],} \\
{\left[\frac{21600-5400 x_{5}-600 x_{1}}{2400}\right],\left[\frac{125-24 x_{5}-8 x_{1}}{16}\right],} \\
{\left[\frac{125-15 x_{5}-6 x_{1}}{10}\right]}
\end{array}\right\}
$$

Sehingga diperoleh:

Jika $x_{5}=x_{1}=0$ maka

$$
\begin{aligned}
& x_{3}^{*}=\min \left\{\begin{array}{c}
{\left[\frac{1200-350(0)-150(0)}{200}\right],\left[\frac{50400-5400(0)-600(0)}{2400}\right],} \\
{\left[\frac{21600-5400(0)-600(0)}{2400}\right],\left[\frac{125-24(0)-8(0)}{16}\right],} \\
{\left[\frac{125-15(0)-6(0)}{10}\right]}
\end{array}\right\} \\
& =\min \{6,21,9,8,12\}=6
\end{aligned}
$$

Perhitungan yang sama dilakukan, maka diperoleh:

Jika $x_{5}=x_{1}=1$ maka $x_{3}^{*}=\min \{3,18,6,6,10\}=3$,

Jika $x_{5}=2, x_{1}=0$ maka $x_{3}^{*}=\min \{2,16,4,5,9\}=2$,

Jika $x_{5}=3, x_{1}=0$ maka $x_{3}^{*}=\min \{1,14,2,3,8\}=1$,

Jika $x_{5}=2, x_{1}=1$ maka $x_{3}^{*}=\min \{2,16,13,4,9\}=2$,

Jika $x_{5}=3, x_{1}=1$ maka $x_{3}^{*}=\min \{0,14,2,3,7\}=0$. 
b. $\quad$ Nilai bilangan bulat terbesar yang mungkin dari $x_{4}$ adalah:

$$
x_{4}^{*}=\min \left\{\begin{array}{c}
{\left[\frac{1200-350 x_{5}-150 x_{1}}{250}\right],\left[\frac{50400-5400 x_{5}-600 x_{1}}{3000}\right],} \\
{\left[\frac{21600-5400 x_{5}-600 x_{1}}{3000}\right],\left[\frac{125-24 x_{5}-8 x_{1}}{20}\right],} \\
{\left[\frac{125-15 x_{5}-6 x_{1}}{12}\right]}
\end{array}\right\}
$$

Sehingga diperoleh:

Jika $x_{5}=x_{1}=0$ maka

$$
\begin{gathered}
x_{4}^{*}=\min \left\{\begin{array}{c}
{\left[\frac{1200-350(0)-150(0)}{250}\right],\left[\frac{50400-5400(0)-600(0)}{3000}\right],} \\
{\left[\frac{21600-5400(0)-600(0)}{3000}\right],\left[\frac{125-24(0)-8(0)}{20}\right],} \\
=\min \{5,17,7,6,10\}=5 .
\end{array}\right\} \\
{\left[\frac{125-15(0)-6(0)}{12}\right]}
\end{gathered}
$$

Perhitungan yang sama dilakukan, maka diperoleh:

Jika $x_{5}=x_{1}=1$ maka $x_{4}^{*}=\min \{3,15,5,5,9\}=3$,

Jika $x_{5}=2, x_{1}=0$ maka $x_{4}^{*}=\min \{2,13,4,4,8\}=2$,

Jika $x_{5}=3, x_{1}=0$ maka $x_{4}^{*}=\min \{1,11,2,3,7\}=1$,

Jika $x_{5}=2, x_{1}=1$ maka $x_{4}^{*}=\min \{1,13,3,3,7\}=1$,

Jika $x_{5}=3, x_{1}=1$ maka $x_{4}^{*}=\min \{0,11,2,2,6\}=0$.

Nilai minimum dari nilai-nilai bilangan bulat terbesar yang diperoleh $x_{2}^{*}=1, x_{3}^{*}=1$ dan $x_{4}^{*}=1$, maka pilih salah satu variabel keputusan yaitu $x_{2}^{*}=1$. Angka 0 tidak dipilih karena 0 merupakan nilai netral. $\bar{x}_{s}=x_{2} \in\{0,1\} .1$ berhubungan dengan $x_{2}^{*}$, dimana 1 adalah nilai bilangan bulat terbesar dari $\bar{x}_{s}$ yaitu $x_{2}^{*}$.

Langkah 6: Asumsikan masalah integer linear programming sebagai $\left(P\left(\bar{x}_{r}, \bar{x}_{t}, \bar{x}_{s}\right)\right)$ untuk setiap $\bar{x}_{r}=x_{5} \in\{0,1,2,3\}, \bar{x}_{t}=x_{1} \in\{0,1\}$ dan $\bar{x}_{s}=x_{2} \in\{0,1\}$ yang melibatkan $5-3$ pada variabel $x_{j}$ dimana $j \neq r, t, s$. Berdasarkan Persamaan (6) permasalahan integer linear programming berubah menjadi:

$$
\begin{aligned}
& \text { Maks } z=30000 x_{1}+50000 x_{2}+75000 x_{3}+100000 x_{4}+150000 x_{5} \\
& \text { kendala: } \\
& 200 x_{3}+250 x_{4} \leq 1200-350 x_{5}-150 x_{1}-200 x_{2} \\
& 2400 x_{3}+3000 x_{4} \leq 50400-5400 x_{5}-600 x_{1}-1200 x_{2} \\
& 2400 x_{3}+3000 x_{4} \leq 21600-5400 x_{5}-600 x_{1}-1200 x_{2} \\
& 16 x_{3}+20 x_{4} \leq 125-24 x_{5}-8 x_{1}-12 x_{2} \\
& 10 x_{3}+12 x_{4} \leq 125-15 x_{5}-6 x_{1}-8 x_{2} \\
& x_{1}, x_{2}, x_{3}, x_{4}, x_{5} \geq 0 \\
& x_{1}, x_{2}, x_{3}, x_{4} \cdot x_{5} \in \text { integer }
\end{aligned}
$$

Langkah 7: Menentukan nilai minimum dari nilai-nilai bilangan bulat terbesar yang mungkin dari $x_{j}$ yang dinotasikan dengan $x_{j}^{*}, j \neq r, t, s$ dalam permasalahan $\left(P\left(\bar{x}_{r}, \bar{x}_{t}, \bar{x}_{s}\right)\right)$ untuk setiap $\bar{x}_{r}=x_{5} \in$ $\{0,1,2,3\}, \bar{x}_{t}=x_{1} \in\{0,1\}$ dan $\bar{x}_{s}=x_{2} \in\{0,1\}$. Kemudian subtitusi $x_{5} \in\{0,1,2,3\}, x_{1} \in\{0,1\}$, dan $x_{2} \in\{0,1\}$ dan ke dalam Persamaan (4):

a. Nilai bilangan bulat terbesar yang mungkin dari $x_{3}$ adalah:

$$
x_{3}^{*}=\min \left\{\begin{array}{c}
{\left[\frac{1200-350 x_{5}-150 x_{1}-200 x_{2}}{200}\right],\left[\frac{50400-5400 x_{5}-600 x_{1}-1200 x_{2}}{2400}\right],} \\
{\left[\frac{21600-5400 x_{5}-600 x_{1}-1200 x_{2}}{2400}\right],\left[\frac{125-24 x_{5}-8 x_{1}-12 x_{2}}{16}\right],} \\
{\left[\frac{125-15 x_{5}-6 x_{1}-8 x_{2}}{10}\right]}
\end{array}\right\}
$$


Sehingga diperoleh:

Jika $x_{5}=x_{1}=x_{2}=0$ maka

$$
x_{3}^{*}=\min \left\{\begin{array}{c}
{\left[\frac{1200-350(0)-150(0)-200(0)}{200}\right],\left[\frac{50400-5400(0)-600(0)-1200(0)}{2400}\right],} \\
{\left[\frac{21600-5400(0)-600(0)-1200(0)}{2400}\right],\left[\frac{125-24(0)-8(0)-12(0)}{16}\right],} \\
{\left[\frac{125-15(0)-6(0)-8(0)}{10}\right]}
\end{array}\right\}
$$

$=\min \{6,21,9,8,12\}=6$.

Perhitungan yang sama dilakukan, maka diperoleh:

Jika $x_{5}=x_{1}=x_{2}=1$ maka $x_{3}^{*}=\min \{2,18,6,5,10\}=2$,

Jika $x_{5}=2, x_{1}=x_{2}=0$ maka $x_{3}^{*}=\min \{2,16,4,5,9\}=2$,

Jika $x_{5}=3, x_{1}=x_{2}=0$ maka $x_{3}^{*}=\min \{1,14,2,3,8\}=1$,

Jika $x_{5}=2, x_{1}=x_{2}=1$ maka $x_{3}^{*}=\min \{1,16,4,3,8\}=1$.

b. Nilai bilangan bulat terbesar yang mungkin dari $x_{4}$ adalah:

$$
x_{4}^{*}=\min \left\{\begin{array}{c}
{\left[\frac{1200-350 x_{5}-150 x_{1}-200 x_{2}}{250}\right],\left[\frac{50400-5400 x_{5}-600 x_{1}-15200 x_{2}}{3000}\right],} \\
{\left[\frac{21600-5400 x_{5}-600 x_{1}-1200 x_{2}}{3000}\right],\left[\frac{125-24 x_{5}-8 x_{1}-12 x_{2}}{20}\right],} \\
{\left[\frac{125-15 x_{5}-6 x_{1}-8 x_{2}}{12}\right]}
\end{array}\right\}
$$

Sehingga diperoleh:

Jika $x_{5}=x_{1}=x_{2}=0$ maka

$$
\begin{aligned}
& x_{4}^{*}=\min \left\{\begin{array}{c}
{\left[\frac{1200-350(0)-150(0)-200(0)}{250}\right],\left[\frac{50400-5400(0)-600(0)-1200(0)}{3000}\right],} \\
\quad\left[\frac{21600-5400(0)-600(0)-1200(0)}{3000}\right],\left[\frac{125-24(0)-8(0)-12(0)}{20}\right], \\
=\min \{5,17,7,6,10\}=5
\end{array}\right\}
\end{aligned}
$$

Perhitungan yang sama dilakukan, maka diperoleh:

Jika $x_{5}=2, x_{1}=x_{2}=0$ maka $x_{4}^{*}=\min \{2,13,4,4,8\}=2$,

Jika $x_{5}=3, x_{1}=x_{2}=0$ maka $x_{4}^{*}=\min \{1,11,2,3,7\}=1$,

Jika $x_{5}=x_{1}=x_{2}=1$ maka $x_{4}^{*}=\min \{2,14,5,4,8\}=2$,

Jika $x_{5}=2, x_{1}=x_{2}=1$ maka $x_{4}^{*}=\min \{1,13,3,3,7\}=1$.

Nilai minimum dari nilai-nilai bilangan bulat terbesar yang diperoleh $x_{3}^{*}$ dan $x_{4}^{*}$ yaitu sama-sama menghasilkan nilai 1 . Oleh karena itu pilih salah satu variabel keputusan seperti $x_{3}^{*}=1$. Angka 0 tidak dipilih karena 0 merupakan nilai netral. $\bar{x}_{y}=x_{3} \in\{0,1\}$. 1 berhubungan dengan $x_{3}^{*}$, dimana 1 adalah nilai bilangan bulat terbesar dari $\bar{x}_{y}$ yaitu $x_{3}^{*}$.

Langkah 8: Asumsikan masalah integer linear programming sebagai $\left(P\left(\bar{x}_{r}, \bar{x}_{t}, \bar{x}_{s}, \bar{x}_{y}\right)\right)$ untuk setiap $\bar{x}_{r}=x_{5} \in\{0,1,2,3\}, \bar{x}_{t}=x_{1} \in\{0,1\}, \bar{x}_{s}=x_{2} \in\{0,1\}$ dan $\bar{x}_{y}=x_{3}^{*} \in\{0,1\}$ yang melibatkan $5-4$ pada variabel $x_{j}$ dimana $j \neq r, t, s, y$. Berdasarkan Persamaan (5) permasalahan integer linear programming berubah menjadi:

Maks $z=30000 x_{1}+50000 x_{2}+75000 x_{3}+100000 x_{4}+150000 x_{5}$

kendala:

$$
\begin{aligned}
& 250 x_{4} \leq 1200-350 x_{5}-150 x_{1}-200 x_{2}-200 x_{3} \\
& 3000 x_{4} \leq 50400-5400 x_{5}-600 x_{1}-1200 x_{2}-2400 x_{3} \\
& 3000 x_{4} \leq 21600-5400 x_{5}-600 x_{1}-1200 x_{2}-2400 x_{3}
\end{aligned}
$$




$$
\begin{aligned}
& 20 x_{4} \leq 125-24 x_{5}-8 x_{1}-12 x_{2}-16 x_{3} \\
& 12 x_{4} \leq 125-15 x_{5}-6 x_{1}-8 x_{2}-10 x_{3} \\
& x_{1}, x_{2}, x_{3}, x_{4}, x_{5} \geq 0 \\
& x_{1}, x_{2}, x_{3}, x_{4} . x_{5} \in \text { integer }
\end{aligned}
$$

Langkah 9: Menyelesaikan sebuah set dari permasalahan integer linear programming yang ada pada Langkah 8 dengan cara:

$$
W=\left\{\begin{array}{c}
\left(x_{1}, x_{2}, x_{3}, x_{4}, x_{5}\right) ; x_{5} \in\left\{0,1,2, \ldots, U_{r}\right\}, x_{1} \in\left\{0,1,2, \ldots, U_{t}\right\}, x_{2} \in\left\{0,1,2, \ldots, U_{s}\right\}, x_{3} \in\left\{0,1,2, \ldots, U_{Y}\right\} \text { dan } \\
x_{4}=\min \left\{\left[\frac{\left[\frac{b_{1}-a_{15} x_{5}-a_{11} x_{1}-a_{12} x_{2}-a_{13} x_{3}}{a_{14}}\right],\left[\frac{b_{2}-a_{25} x_{5}-a_{21} x_{1}-a_{22} x_{2}-a_{23} x_{3}}{a_{24}}\right],}{\left[\frac{b_{3}-a_{35} x_{5}-a_{31} x_{1}-a_{32} x_{2}-a_{33} x_{3}}{a_{34}}\right],\left[\frac{b_{4}-a_{45} x_{5}-a_{41} x_{1}-a_{42} x_{2}-a_{43} x_{3}}{a_{44}}\right],}\right.\right. \\
{\left[\frac{b_{5}-a_{55} x_{5}-a_{51} x_{1}-a_{52} x_{2}-a_{53} x_{3}}{a_{54}}\right],}
\end{array}\right\}
$$

Kemudian subtitusi $x_{5} \in\{0,1,2,3\}, x_{1} \in\{0,1\}, x_{2} \in\{0,1\}$ dan $x_{3} \in\{0,1\}$ ke Persamaan (6) berikut:

$$
x_{4}=\min \left\{\begin{array}{c}
{\left[\frac{b_{1}-350 x_{5}-a_{11} x_{1}-a_{12} x_{2}-a_{13} x_{3}}{a_{14}}\right],\left[\frac{b_{2}-a_{25} x_{5}-a_{21} x_{1}-a_{22} x_{2}-a_{23} x_{3}}{a_{24}}\right],} \\
{\left[\frac{b_{3}-a_{35} x_{5}-a_{31} x_{1}-a_{32} x_{2}-a_{33} x_{3}}{a_{34}}\right],\left[\frac{b_{4}-a_{45} x_{5}-a_{41} x_{1}-a_{42} x_{2}-a_{43} x_{3}}{a_{44}}\right],} \\
{\left[\frac{b_{5}-a_{55} x_{5}-a_{51} x_{1}-a_{52} x_{2}-a_{53} x_{3}}{a_{54}}\right],}
\end{array}\right\}
$$

Sehingga diperoleh:

Jika $x_{5}=x_{1}=x_{2}=x_{3}=0$ maka

$$
\begin{aligned}
&= \min \left\{\begin{array}{c}
{\left[\frac{1200-350(0)-150(0)-200(0)-200(0)}{250}\right],\left[\frac{50400-5400(0)-600(0)-1200(0)-2400(0)}{3000}\right],} \\
{\left[\frac{21600-5400(0)-600(0)-1200(0)-2400(0)}{3000}\right],\left[\frac{125-24(0)-8(0)-12(0)-16(0)}{20}\right],} \\
\quad=\min \{4,16,7,6,10\}=4 .
\end{array}\right\} \\
&\left.\hline \frac{125-15(0)-6(0)-8(0)-10(0)}{12}\right]
\end{aligned}
$$

Perhitungan yang sama dilakukan, maka diperoleh:

Jika $x_{5}=x_{1}=x_{2}=x_{3}=1$ maka $x_{4}=\min \{1,13,4,3,7\}=1$,

Jika $x_{5}=2, x_{1}=x_{2}=x_{3}=0$ maka $x_{4}=\min \{2,13,3,3,7\}=2$,

Jika $x_{5}=3, x_{1}=x_{2}=x_{3}=0$ maka $x_{4}=\min \{0,11,1,2,6\}=0$.

Langkah 10: Menentukan calon solusi optimum.

Berdasarkan hasil yang diperoleh pada Langkah 9 maka dapat ditentukan calon solusi optimum sebagai berikut:

Jika $x_{5}=x_{1}=x_{2}=x_{3}=0, x_{4}=4$ maka $z=30(0)+50(0)+75(0)+100(4)+150(0)=40$

Jika $x_{5}=x_{1}=x_{2}=x_{3}=1, x_{4}=1$ maka $z=30(1)+50(1)+75(1)+100(1)+150(1)=405$

Jika $x_{5}=2, x_{1}=x_{2}=x_{3}=0, x_{4}=2$ maka $z=30(0)+50(0)+75(0)+100(2)+150(2)=500$

Jika $x_{5}=3, x_{1}=x_{2}=x_{3}=0, x_{4}=0$ maka $z=30(0)+50(0)+75(0)+100(0)+150(3)=450$

Berdasarkan penyelesaian di atas, solusi optimum untuk kasus maksimum diperoleh dengan nilai $x_{4}=x_{5}=2$ dan fungsi $z=500$. Artinya bingkai foto yang diproduksi oleh ZEE Studio Photography yaitu 2 bingkai foto ukuran 24R dan 2 bingkai foto ukuran 36R dengan keuntungan yang diperoleh sebesar Rp.500.000.

\section{Kesimpulan}

Berdasarkan hasil penelitian maka diperoleh kesimpulan sebagai berikut:

Metode reduksi variabel menghasilkan solusi optimal dengan semua variabel keputusan berupa bilangan bulat dengan perhitungan yang lebih sederhana tanpa harus menambah kendala gomory ataupun membuat percabangan. Berdasarkan pengolahan data diperoleh solusi optimum yaitu 
$x_{1}=0, x_{2}=0, x_{3}=0, x_{4}=2$ dan $x_{5}=2$ dengan $z=500$. Artinya ZEE Studio Photography memperoleh keuntungan sebesar Rp.500.000 dengan memproduksi 2 bingkai foto ukuran 24R dan 2 bingkai foto ukuran 36R.

\section{Daftar Pustaka}

[1] Basriati, Sri., Integer Linear Programming Dengan Pendekat an Metode Cutting Plane Dan Branch And Bound Untuk Optimasi Produksi Tahu, Jurnal Sains Matematika dan Statistika, Vol. 4, No 2, 2018.

[2] Dimyati, T.T., dan Dimyati. A ., Operations Research: Model-model Pengambilan Keputusan, CV. Sinar Baru Algensindo, Bandung, 2009.

[3] Marantika, Eagar, dkk., Penerapan Metode Branch and Bound Dalam Menentukan Keuntungan Maksimum Penjualan Tempe, Seminar Nasional Pendidikan Matematik, 2017. 299-309.

[4] Novtaria, Pesti dan S. Bahri. Penyelesaian Masalah Pemrograman Linear Bilangan Bulat Murni Dengan Metode Reduksi Variabel, Jurnal Matematika UNAND, Vol. 3, No 3, 2014. 17-25.

[5] Nufus, M., dan J. Anggara, Riset Operasi, Daulat Riau, Pekanbaru, 2016.

[6] Pandian, P., dan M. Jayalakshmi, A New Approach for Solving A Class Of Pure Integer Linear Programming Problems, International Journal Of Advanced Engineering Technology, Vol. III, 2012. 248-251.

[7] Siang, J. J., Riset Operasi Dalam Pendekatan Algoritmis, Andi, Yogyakarta. 2011.

[8] Siswanto, Operations Research Jilid 1, Erlangga, Jakarta. 2007.

[9] Supatimah, Sri Siti, dkk., Optimasi Keuntungan Dengan Metode Branch And Bound, Jurnal Matematika dan Pendidikan Matematik, Vol. 10, No 1, 2019.

[10] Wifaulita, W., Metode Cutting Plane Pada Penyelesaian Integer Linear Programming Problem, Tugas Akhir, Program Studi Matematika, Universitas Islam Negeri Sultan Syarif Kasim Riau, Pekanbaru, 2016. 